\title{
Economic Development and Civil Society
}

\author{
Aigum Aigumov ${ }^{*}$
}

\author{
${ }^{1}$ Dagestan State University, Russia \\ *Email: gimu.kafedra@yandex.ru
}

\begin{abstract}
In the article discusses the prospects of post-crisis development of the Russian economy. The role of forming a terraced civilisation in Dagestan, the agricultural terracing of land and the formation of appropriate forms of public power with private property and citizens' political equality, the modification of local communities adapted to the technogenic environment into a civil community is studied. Within the study framework, the author focused on the problems of developing civil society and the choice of development strategy in the whole federation and its subjects. The conducted research allows us to state that a developed civil society and the need to use Dagestan's historical experience for modern self-government reforms and civil society's formation are indispensable conditions for a democratic form of government.
\end{abstract}

Keywords: Terraced civilizations, Civil community, Self-government, polis, Elective public power, Citizens' rights.

\section{INTRODUCTION}

The Russian economy's post-crisis development in Russian literature is usually considered in connection with human capital, investment, and innovation. Simultaneously, insufficient attention is paid to the development of civil society and political competition, collective interests, and the objective basis for civil society formation.

By the end of 2020, according to the IMF, GDP per capita in the Russian Federation will be $\$ 9970,14 \%$ less than in 2019. This is the 68th place in the world and the level of 2007. According to the fund's calculations, the Russian economy's growth after quarantine will be almost twice as slow (5.2\%) as the global average. Currently, Russia is 4.5 times behind the developed countries in terms of living standards - $\$ 46,350$ per capita. In 2025 , this figure will increase to $\$ 58,650$, and the gap will become almost 5 times. China has already overtaken Russia, whose GDP per capita will be $\$ 10,840$ in 2020 and $\$ 16,280$ in 2025.

Of the Eastern European countries, only Bulgaria is one place behind Russia in the ranking. The IMF believes that by 2025 this figure will be $\$ 13,090$ and 66th place. For a place in the ranking in terms of GDP per capita,
Russia remains to compete with Turkmenistan, which is now ahead by $20 \%$. This gap by 2025 it will be almost eliminated. The GDP per capita in Turkmenistan will be $\$ 12,850$, which is $\$ 85$ less than in the Russian Federation $(\$ 12,970)$. These are the competition results with developed countries, which was the goal of the country's economic policy, stemming from Marxist postulates. It was assumed that the developed countries set an example to the backward and should catch up with them and equal them. This idea was especially prevalent during the first five-year plans. Thus, in Stalin's speeches, it was emphasised that socialist Russia needed 50 years (in another place, 100 years) to catch up with the advanced capitalist countries in industrial production. The most famous was the failed attempt under N.S. Khrushchev to catch up and overtake the United States in meat and milk.

The principle of catch-up development has many supporters. At the same time, in the public lectures of the Dean of the Faculty of Economics of Moscow State University A. Auzan in the Polytechnic Museum (recognised as the best in 2008), it was shown that the gap between developed countries, countries with an average level of development and backward countries according to A. Auzan's gradation is not only not decreasing, but on the contrary, is increasing more and more. Statistics for a considerable time show that many 
countries did not know how they were developing. Their development was based not on a wise economic policy, not on the availability of natural resources, but on a developed civil society, an uncorrupted government, and citizens' trust in the government, incorruptible courts, a free press, etc. [1].

And if there were some examples of the transition of backward countries to advanced ones, for example, Japan, then the leading role here, as A. Auzan noted, was played by supra-constitutional rules, some unwritten laws are of considerable interest. The need to catch up prevailed in the works of Russian Eurasians. Even Duke N. Trubetskoy noted in his works that the RomanoGermans do not have an advantage over other peoples, and if the backward peoples on the ladder of evolution catch up with them, the Europeans will again go far ahead [2]. "Call to catch up", as I.R. Shafarevich wrote, "it is generally precarious if it belongs to the social field, and not to real runners. An attempt to repeat someone else's work (and history is a creative process) usually leads not to an exact copy, but second-class products. Only by finding some way of their own, it is possible to reach the same or higher level" [3, p.271].

\section{POST-CRISIS ECONOMIC DEVELOPMENT OF RUSSIA}

The Accounts Chamber of the Russian Federation in its macroeconomic forecast believes that the preguarantee indicators for the level of real GDP and the Russian Federation's unemployment rate will reach by the end of 2023. The pace of economic recovery in the Accounting Chamber is even less optimistic. The main factor affecting Russia's economic situation, the Accounts Chamber considers not so much quarantine as oil prices. With all the scenario oil prices, the authors of the forecast predict that the GDP growth rate of the Russian Federation will be significantly lower than the global economy.

Several countries cannot cross the level of 10-12 thousand dollars per capita GDP, the so-called "middleincome trap". In principle, any country can achieve this indicator by selling raw materials or reducing the share of wages in production costs, which in Marxism's political economy was called "overexploitation". But to cross this line, simple mechanisms for exploiting people and selling the country's resources are no longer enough. The issues of human capital, investment and innovation play an essential role and are widely discussed in Russian literature. The following conditions are also necessary: a developed civil society and political competition, following the path of advanced democratic countries and that these developed countries want to support this development. An important factor is the involvement of more and more people in creating and accumulating wealth. The interest of the state leadership and the ruling elite in the general collective interests, as opposed to short-term private interests, is necessary. This implies a reduction in the elite's excess income favouring the population's low-income segments, creating a middle class. As part of our research, we will focus on the problems of civil society development and the choice of development strategy in the whole federation and its subjects.

The increased interest in the civil society's operational problems in our country is closely related to developing the local self-government system and local self-government reform. The point of view on local selfgovernment as a fundamental principle of the exercise of power in society and the State seems fruitful. The organisation of local self-government creates favourable conditions for the development of genuine democracy. The participation of the population in solving local issues increases the level of its political culture and contributes to citizens' involvement in the process of public administration. The most critical component of civil society's influence on the management system is to overcome alienation and broad involvement of the population in the management process.

Currently, both at the federal and regional levels, the underdevelopment of civil society institutions does not allow controlling the activities of state and municipal government structures, making and implementing state decisions, effectively fighting corruption, and helping to solve the problem of optimising state structures and the management apparatus.

\section{THE ECONOMIC SYSTEM AND THE LEVEL OF DEVELOPMENT OF CIVIL SOCIETY AND THEIR IMPACT ON THE PATTERNS OF SOCIO-ECONOMIC DEVELOPMENT}

As we have already noted, the already increased interest in civil society's problems does not always affect the differences in governance forms and the corresponding level of development of civil society from the existing economic system. However, forming a civil society has an objective basis, and its artificial acceleration is not fruitful. Civil society is a component of citizens with a developed civic consciousness. Developing civic consciousness is the prerogative of the individual himself and follows from local selfgovernment institutions' improvement. There are many examples of this. As he wrote to Margaret Thatcher: "Yet sound institutions alone do not guarantee democracy. This is confirmed by attempts to plant the seeds of freedom in societies with no suitable conditions for their acceleration. They turn out to be useless and even dangerous. For freedom to take root, a critical mass of people who understand what it is necessary. Such an understanding cannot come from simply reading books; only customs and worldviews make freedom sustainable. 
In other words, first, there are free people, and only then there is a free political, economic and social order" [4, p.500]. A striking example of this situation is introducing democratic institutions after the First World War in Eastern Europe countries. So, in Poland, a coup organised by Marshal Pilsudski brought to power the military loyal to him. Formally, democracy was preserved; in fact, resistance to the will of the marshal was suppressed. The pre-war period of Poland's development was marked as a parody of a dictatorship and a parliament steeped in a comprehensive system of patronage.

In the "Reflections of a Nonpolitical Man", Thomas Mann wrote that "the education of the people and youth through art is a risky undertaking that should be banned" [5, p.527]. He also has another insight that culture does not save from anything and favours totalitarianism if you like. This is the most important result of the 20th century. It was believed that the culture of the Germans should protect them from fascism. But the culture never protects against the dictatorship. It is compatible with dictatorship [5, pp.521-542].

Neither the culture nor the democratic institutions did not save Italy from fascism. The famous Italian director Federico Fellini, who created by universal recognition the best film about fascism - "Amarcord" wrote that in addition to the objective reasons that contribute to the formation of fascism, no less important is the superficial erudition, the spirit of competition, the thirst for profit [7].

In the world literature, the distinction between states' socio-economic development is divided into eastern and western. Since this division is more or less determined, the interpretation of the history of Russia is controversial. Although, in fairness, I must say that there were contradictions in the original division into East and West. Ancient Greeks believed the East that was in front of them when they were in the direction of Asia Minor, and that behind it was the West African country's Mediterranean coast, for some reason thought East. Kyivan Rus in literature before the Tatar-Mongol invasion was considered a European country, clothing was like the Germans and Czechs, and marriages with Europeans were, Novgorodians and Pskovites had close trade relations with European countries. However, many believe that even then Kyivan Rus was quite different from Western Europeans. After the Mongol yoke until the 17th century, it was even more separated from the Western path of development, approaching the "Eastern despotism". The fluctuation between eastern and western models of development runs like a red thread through Russian history. Peter's reforms and transformations of the $90 \mathrm{~s}$ of the 20th century are considered an unsuccessful demonstration to become a "normal" European country. The difficulties of Europeanisation of Russia are staked out by monocentrism and the formation theory of K. Marx.
"For a long time," writes L.N. Gumilev, "the scientific thought of the historians of Europe was trapped in an iron ring of monocentrism. From the era of F. Gegel seemed obvious that civilisation's development went through ancient Judea, Hellas, Rome and found its completion in Western Romano-Germanic Europe, surrounded by "unhistorical" or "backwards" peoples. Chinese historians thought similarly, with the only exception that they considered the centre of civilisation to be the "Middle Plain", which was fenced off from the Great Steppe by a "Long Wall" [8, p.5]. "When the British delegation to China showed the globe to the hosts in August 1793, there was a diplomatic row because the Chinese were offended by how small their empire was. For centuries, the Chinese have thought of themselves as the "Middle Kingdom", the civilised world's centre. A different opinion caused a shock" [9, p. 190]. In South Asia, semi-continent India <...> was considered by scientists as the only country worthy of attention [9, p.5]. $\langle\ldots>$ Also, to these centres of narcissism and selfaggrandisement were other regions, including Eurasia, the country with the original nature, diverse population and unique culture, "has long been overlooked, in consequence of which it was considered non-existent. However, both the Chinese and Europeans were convinced how wrong this opinion was" [11, p.5].

But the linear-progressive scheme, based on the Eurocentric approach and the cult of progress, continued to be dominant in the Western European philosophy of history during the 18th and 19th centuries. By the same idea, Russia was pinned to Asiaticism for its ties with the Golden Horde, and its outskirts, including Dagestan, were at the lowest point on the "ladder of evolution" of humanity in general. It should be noted that this point of view was not shaken at all during the Soviet period. The point of view of Academician Grekov "Primitive forms of feudal exploitation in the conditions of patriarchal life and non-lived tribal relations" on the historical development of the North Caucasian and Asian peoples of Russia triumphed.

In addition to the formation theory, the civilisational approach, which has various directions, has received significant world practice development. A.Toynbee identified 21 civilizations in history, later he reduced their number to 13 , excluding secondary, secondary and underdeveloped ones. He regarded Western civilisation as one of the 21 and no more. Speaking on behalf of Western society, he stated that we do not recognise other societies of equal value globally [12].

The most fruitful in the interpretation of various management systems is the bilinear theory of $K$. Wittfogel, which assumes a general difference in the forms of management in the East and West, depending on the existing forms of ownership [13]. Wittfogel's concept of an "eastern" society is based on many people's forced labour in irrigation work and control over primary 
life resources. The preserved archival materials in Mesopotamia, Egypt, China, as well as the records of the Spanish conquistadors about the Inca state in America allow us to characterise these states as socialist since in these states the socialist ideals were implemented more fully and consistently than in the first socialist State of the workers and peasants of Soviet Russia. This system gave rise to an all-powerful bureaucracy with totalitarian governance.

\section{MANAGEMENT SYSTEM IN THE CONDITIONS OF AGRICULTURAL TERRACING OF MOUNTAIN SLOPES}

As noted by the researcher Aglarov M.A. "Since ancient times, the Eastern Mediterranean and the Caucasus have been following a parallel Eastern, Western (Greco-Roman) path of civilisational development, the essence of which was the creation of a society based on a dual combination of public and private forms of ownership, the rights of civil communities to delimited territories, sovereign self-government, political equality of citizens and public law" [11, p.6-7].

Artificial irrigation of soils in the plains of ancient Egypt, the states between the Tigris and Euphrates rivers and in the basins of other large rivers of Asia, which was carried out by a single centrally managed irrigation network, led to the establishment of the states themselves with a unitary management system. In these States, land ownership and all means of production and management functions are concentrated in the hands of the ruling class and the State administration. K. Wittfogel united states of this type into hydraulic civilizations. Simultaneously, mountain and mountain-valley irrigation and land terracing were relatively autonomous and adapted to the mountain landscape. The agricultural terracing of the mountain slopes of Dagestan dates back to the Middle Bronze Age and extends throughout the Eastern Mediterranean up to the Basque Country. The Southern and Eastern Caucasus was the initial centre of terrace technologies that spread through the "golden belt" of ancient agricultural civilizations [12, p.29-35].

The massive transformation resulting from the agricultural terracing of mountain slopes has contributed to the creation of management systems adapted to human-made local landscapes. In contrast to hydraulic in the literature, they are called terraced civilizations. In hydraulic civilizations, local communities were transformed into dependent urban and peasant communities. The State here is built according to a pyramid scheme. At the top of the power, the supreme ruler, the sidelines - the priesthood and bureaucracy, the pyramid's base - the urban lower classes and peasant communities. "The basis of peasant communities was a joint settlement, peasant labour, a collective form of land use, the absence or extreme restriction of sovereignty in self-government, the absence of military organisation, social, "legal dependence on the higher strata or "high community". In terraced civilizations that have developed based on political formations such as polis, without a state, but with developed institutions of selfregulation (the ancient world in its early history, the Caucasus, some areas of the Balkans, Baskonia, etc.), the community is modified into its highest form - a civil community. "The civil community is based on the fullness of the rights of self-government, the organisation of elected public power and the existence of citizens' rights to private property, including the rights to private land ownership" [13, p.14].

\section{CONCLUSIONS}

The Western way of development is characterised by a society with private property and political equality of citizens, in contrast to the Eastern way, with a hierarchy of political power, undifferentiated land ownership. At the same time, the organisation of power and the forms of administration in the South-Eastern Caucasus have rare analogies in history, if they exist at all, and quite definitely reproduce the schemes of government of the ancient polis of Ancient Greece.

For example, in Dagestan, there were democratic public power organisations, based partly on public and partly on customary law. In the history of the Dagestanis and the individual peoples of the Caucasus, selfgovernment in the form of civil communities was perhaps the most critical part of their social and political life. Moreover, in most cases, the only form of their political self-organisation.

Self-government in the form of civil communities existed in Dagestan from late antiquity to the Caucasian War. The historical experience of democratic forms of government in Dagestan is vital for modern selfgovernment reforms and the further development of civil society.

\section{REFERENCES}

[1] Hernando de Soto, Another way, Chelyabinsk: Socium, 2007, 408 p.

[2] N. Trubetskoy, Europe and humanity, Moscow, 2015, 113 p.

[3] I.R. Shafarevich, "Two roads to one cliff", Moscow, Iris-Press, 2003, p. 271.

[4] M. Thatcher, Art of state management, 2014, p. 504.

[5] T. Mann, Reflections of a Nonpolitical Man, Moscow, 2015, p. 542.

[6] F. Fellini, "Making a movie", Documentary prose, Torino 1980.

[7] L.N. Gumilev, Millennium around the Caspian Sea, Moscow, 2008, p. 384. 
[8] M. Thatcher, Statecraft: Strategies for a Changing World, 2014, p. 504.

[9] L.N. Gumilev, Millennium around the Caspian Sea. Moscow, 2008, p. 384.

[10] A. Toynbee, Research of history, ch. 12. Prospects of Western civilisation. Moscow, 2009, p. 1072.

[11] M.A. Aglarov, Ethnogenesis in the light of polyanthropology and ethnonymics in Dagestan, Makhachkala, 2013, p. 287.

[12] K. Wittfogel, Oriental despotism. Study of Total Power, New Haven: Yale University Press, 1957.

[13] M.A. Aglarov, Terraced agriculture in Mountainous Dagestan, Nature 12 (2008) 29-35. 